\title{
Evaluation of disease forecasting programs for management of septoria late blight (Septoria apiicola) on celery
}

\author{
C.L. Trueman, M.R. McDonald, B.D. Gossen, and A.W. McKeown
}

\begin{abstract}
Septoria late blight caused by Septoria apiicola damages celery leaves (Apium graveolens), but its main impact is on the marketability of petioles. Three field trials (two in 2005 and one in 2006) were conducted at the Holland-Bradford Marsh, Ontario, to determine whether the number of fungicide applications required to manage septoria late blight could be reduced compared with the standard calendar spray program and whether disease management could be improved. Two disease forecasting programs (Tomcast at three disease severity value (DSV) thresholds and the Septoria Predictor) were assessed relative to a 7-day calendar spray program and a nonsprayed control. Each fungicide timing treatment, which entailed application of the fungicide Bravo 500 (chlorothalonil 50\% a.i.) alternating with Champ 2FL (copper hydroxide 37.5\% a.i.), was compared with Pristine WG (pyraclostrobin $12.8 \%$, boscalid $25.2 \%$ a.i.) alternating with Champ $2 \mathrm{FL}$ on each of two celery cultivars. Pristine consistently provided superior control of septoria late blight compared with Bravo. Treatments were applied to two susceptible celery cultivars 'Florida 683' and 'Sabroso'. Both cultivars responded in a similar manner to the treatments. Fungicide applications timed according to Tomcast at a DSV threshold of 10 or the Septoria Predictor resulted in septoria late blight severity levels on leaves and petioles comparable to the calendar spray program. Fungicide applications were reduced by 1 for the Septoria Predictor, by 1 to 3 for Tomcast at DSV threshold 10, and by 2 to 4 for Tomcast at DSV threshold 15. However, a yield reduction of $15 \%$ occurred in one trial when application of Bravo/Champ were timed according to Tomcast at DSV 15, indicating that the DSV 15 threshold was not always adequate for septoria late blight management using Bravo.
\end{abstract}

Key words: disease management, Tomcast, Septoria Predictor, integrated pest management, fungicide, Apium graveolens var. dulce.

Résumé : La septoriose (brûlure tardive) (Septoria apiicola) endommage les feuilles de céleri (Apium graveolens), mais c'est sur la qualité marchande des pétioles que son impact principal se fait sentir. Trois essais au champ (deux en 2005 et un en 2006) furent effectués dans le marais Holland-Bradford, Ontario, afin de déterminer si le nombre d'applications de fongicides nécessaires pour lutter contre la septoriose pouvait être réduit comparativement au calendrier courant de pulvérisations et si la lutte contre la maladie pouvait être améliorée. Deux programmes de prévision des maladies (le Tomcast à trois seuils de valeur d'intensité de maladie (DSV) et le Septoria Predictor) furent évalués en ce qui a trait à un calendrier d'applications de 7 jours et un témoin non traité. Pour chaque traitement fongicide prévu, l'application du fongicide Bravo 500 (chlorothalonile à $50 \%$ de matière active) en alternance avec le Champ 2FL (hydroxyde de cuivre à 37,5\% de matière active), fut comparée au Pristine WG (pyraclostrobine à $12,8 \%$, boscalide à 25,2 \% de matière active) en alternance avec le Champ 2FL sur chacun des deux cultivars de céleri. Le Pristine a invariablement procuré une meilleure lutte contre la septoriose comparativement au Bravo. Les traitements furent appliqués à deux cultivars de céleri sensibles, 'Florida 683' et 'Sabroso'. Les deux cultivars ont eu une réponse similaire aux traitements. Les applications de fongicides prévues par le Tomcast à un seuil de DSV de 10 ou par le Septoria Predictor ont donné des degrés de septoriose sur les feuilles et les pétioles comparables à ceux obtenus avec le calendrier courant de pulvérisations. Le nombre d'applications de fongicides fut réduit de 1 dans le cas du Septoria Predictor, de 1 à 3 dans le cas du Tomcast à un seuil de DSV de 10, et de 2 à 4 dans le cas du Tomcast à un seuil de DSV de 15. Cependant, dans un essai, une réduction du rendement de $15 \%$ s'est produite lorsque

Accepted 27 September 2007.

C.L. Trueman and M.R. McDonald. ${ }^{1}$ Department of Plant Agriculture, University of Guelph, Guelph, ON N1G 2W1, Canada. B.D. Gossen. Saskatoon Research Centre, Agriculture and Agri-Food Canada, Saskatoon, SK S7N 0X2, Canada.

A.W. McKeown. Department of Plant Agriculture, Simcoe Research Station, University of Guelph, Simcoe, ON N3Y 4N5, Canada.

${ }^{1}$ Corresponding author (e-mail: mrmcdona@uoguelph.ca). 
l'application de Bravo/Champ fut prévue en fonction du Tomcast au seuil DSV de 15, ce qui indique que le seuil de DSV de 15 n'était pas toujours adéquat pour lutter contre la septoriose en utilisant le Bravo.

Mots-clés : lutte contre les maladies, Tomcast, Septoria Predictor, lutte intégrée contre les parasites, fongicide, Apium graveolens var. dulce.

\section{Introduction}

Septoria late blight, which is caused by Septoria apiicola Speg., is an important disease of celery (Apium graveolens L. var. dulce (P. Mill.) Pers.) worldwide (Sutton and Waterston 1966). Yield loss $\leq 70 \%$ can occur (Lacy et al. 1996). For processing celery, lesions on petioles can result in a crop that is not marketable and thus have an even larger economic impact than direct yield loss. Favourable conditions for septoria late blight development are common in Canada, and the disease has been reported in all Canadian provinces (Cerkauskus 1994).

Inoculum is often transported from infected to noninfected fields by infected seed and crop residue or as conidia on farm workers and equipment (Maude 1970; Maude and Shuring 1970; Sutton and Waterston 1966). Lesions appear 8-15 days after infection, and pycnidia rapidly develop within the lesions (Lacy 1994). Conidia are released from the pycnidia when leaves are wet and are spread via rain-splash, causing secondary infections within the celery crop (Sutton and Waterston 1966). Leaf wetness duration $\geq 12 \mathrm{~h}$ and air temperatures from 10 to $30{ }^{\circ} \mathrm{C}$ are the key environmental factors that contribute to infection (Mathieu and Kushalappa 1993).

Septoria late blight is difficult to control once present in a field (Mudita and Kushalappa 1993), and celery growers must rely on application of foliar fungicides to manage this disease. The labour requirements to trim fresh-market celery with lesions are high, and loads of processing celery showing disease symptoms can be rejected entirely, therefore disease tolerance thresholds are low. Fungicides are applied on a calendar schedule as soon as symptoms are observed in the field or beginning one-third of the way through the growing season (OMAFRA 2006). Cultural practices for disease management include using 3-year-old seed, crop rotation, and limiting entry of workers and equipment into fields when foliage is wet. These techniques may prevent or delay initial infections, but epidemics develop quickly and cause severe losses when environmental conditions are conducive for disease increase (Lacy et al. 1996). No threshold level for septoria late blight has been established because expected crop losses substantially exceed the cost of one fungicide application (Mudita and Kushalappa 1993).

Accurate disease forecasting can reduce the number of fungicide applications by triggering spray applications only when required to minimize disease increase. No disease forecasting system has been validated for septoria late blight in Ontario. However, forecasting systems based on leaf wetness duration and air temperature have been developed for other systems or locations (Lacy 1994; Mathieu and Kushalappa 1993; Phillips 1999). Two systems, the Septoria Predictor and Tomcast, have the potential to be used as decision support tools for timing of fungicide applications in Ontario. The Septoria Predictor is a simple system that was developed for septoria late blight in Michigan (Lacy 1994). Before the celery canopy is large enough to close over the rows, fungicide is applied when leaves have been wet for more than $12 \mathrm{~h}$. Once the canopy closes, regular fungicide applications (7- to 10-day intervals) are recommended.

Tomcast was developed in Ontario to manage leaf blights and anthracnose on tomato (Poysa et al. 1993) and is based on the FAST model for Alternaria solani Sorauer (Madden et al. 1978). Although it was not developed for S. apiicola, the model was used successfully to manage late blight of celery in California. Tomcast, used in conjunction with insect monitoring, reduced pesticide applications on celery by 12 sprays in 1992 and 9 sprays in 1993 (Bolkan and Reinert 1994).

Boscalid and strobilurin fungicides, such as pyraclostrobin, provide alternatives to older chemistries for diseases caused by fungal pathogens on a number of horticultural crops (OMAFRA 2006). These fungicides are not yet registered for use on celery in Canada, but a combination of pyraclostrobin and boscalid provided effective management of septoria late blight when used in a 7-10 day calendar spray program (Trueman et al. 2005). The risk of fungi developing resistance to strobilurin fungicides is relatively high (FRAC 2005). Inclusion of boscalid with pyraclostrobin reduces risk of resistance development to pyraclostrobin. This risk would be further mitigated by rotation of fungicide chemistries and disease forecasting to minimize the number of fungicide applications per season.

The objective of this research was to improve decision support tools for management of septoria late blight by testing the efficacy of the Tomcast and Septoria Predictor forecasting programs under conditions found in Ontario. Application of disease forecasting systems for septoria late blight may improve disease management, reduce grower costs, and reduce the environmental impact associated with disease management by reducing the number of fungicide applications each season. Effective disease management can also improve crop quality.

\section{Materials and methods}

\section{Trial location and layout}

Two field trials in 2005 and one trial in 2006 were conducted on organic soil ( $\mathrm{pH} \sim 6.8$, organic matter $\sim 40 \%$ ) near the Muck Crops Research Station, Holland-Bradford Marsh, Ontario $\left(44^{\circ} 15^{\prime} \mathrm{N}, 7^{\circ} 90^{\prime} \mathrm{W}\right)$. Processing cultivar 'Sabroso' (Pybas Vegetable Seed Co., Santa Maria, Calif.) and fresh market cultivar 'Florida 683' (Pybas Vegetable Seed Co.) were seeded into 288-cell plastic plug trays (Landmark 
Table 1. Criteria for calculation of disease severity values (DSVs) used in the Tomcast disease forecasting system (Madden et al. 1978).

\begin{tabular}{lllllll}
\hline \multicolumn{3}{c}{ Mean temperature } & \\
\cline { 2 - 5 } & $13-17{ }^{\circ} \mathrm{C}$ & $18-20{ }^{\circ} \mathrm{C}$ & $21-25{ }^{\circ} \mathrm{C}$ & $26-29{ }^{\circ} \mathrm{C}$ & DSVs \\
\hline Leaf wetness duration (h) & $0-6$ & $0-3$ & $0-2$ & $0-3$ & 0 \\
& $7-15$ & $4-8$ & $3-5$ & $4-8$ & 1 \\
& $16-20$ & $9-15$ & $6-12$ & $9-15$ & 2 \\
& $21+$ & $16-22$ & $13-20$ & $16-22$ & 3 \\
& - & $23+$ & $21+$ & $23+$ & 4 \\
\hline
\end{tabular}

Plastic Corp., Akron, Ohio) on 15 March 2005 (Trial 1), 14 April 2005 (Trial 2), and 27 March 2006 (Trial 3). Seedlings were transplanted by hand into the field on 25 May 2005, 23 June 2005, and 19 May 2006, respectively. There were three rows per plot, each $5 \mathrm{~m}$ in length, and rows were spaced $55 \mathrm{~cm}$ apart. In Trials 1 and 3, in-row plant spacing was $15 \mathrm{~cm}$ for 'Florida 683' and $18 \mathrm{~cm}$ for 'Sabroso'. For Trial 2, in-row plant spacing was $22 \mathrm{~cm}$ for 'Florida 683' and $15 \mathrm{~cm}$ for 'Sabroso' because the cultivars were mislabelled at seeding by the supplier.

\section{Fungicides, timing, and method of application}

Five fungicide timing treatments were assessed, each with two fungicide spray regimes. These 10 treatments plus a nonsprayed check gave a total of 11 treatments as the main plot factor. Cultivar was the split-block factor. Cultivars were not randomized within main plots to avoid confusion while transplanting. The five fungicide timing treatments assessed in each trial were a 7-day calendar spray program, Tomcast with a disease severity value (DSV) threshold of 10,15 , or 20, and the Septoria Predictor. Fungicide applications using the Septoria Predictor were applied after a leaf wetness period $\geq 12 \mathrm{~h}$ if the treatment had not been sprayed within the past 7 days and the canopy was not fully closed (Lacy 1994). A regular 7-10 day spray program was implemented after the crop canopy closed. Tomcast treatments were based on accumulated DSVs from 0 to 4 per wetness period over a 24-h interval (Madden et al. 1978) that depended on leaf wetness duration and temperature (Table 1). Fungicides were applied for Tomcast treatments when 10, 15, or 20 DSVs had accumulated, depending on the treatment threshold. The actual timing of application varied by \pm 2 DSV units from the threshold because of early or delayed sprays as a result of rain or high wind conditions.

Each fungicide timing treatment was evaluated using the following two fungicide regimes: (i) Bravo 500 (chlorothalonil 50\% a.i., Syngenta Crop Protection Canada, Inc., Guelph, Ont.) alternating with Champ 2FL (copper hydroxide $37.5 \%$ a.i., NuFarm, Melbourne, Australia); and (ii) Pristine WG (pyraclostrobin $12.8 \%$, boscalid $25.2 \%$ a.i., BASF Canada Corp., Mississauga, Ont.) alternating with Champ. The Bravo 500 rotation was chosen to represent a management program currently available to Ontario celery growers, whereas the Pristine rotation was chosen as a prospective reduced-risk pesticide option due to lower user rates, low resistance potential, improved efficacy, and compatibility with integrated pest management. Champ is not registered for use on celery in Canada; however, copper sulphate and copper oxychloride (chemically similar to copper hydroxide) are registered for this use (OMAFRA 2006).

Fungicide treatments were applied using a pull-type plot sprayer with TeeJet D-3 hollow-cone nozzles (TeeJet Technologies, Wheaton, Ill.) at $690 \mathrm{kPa}$ (boom) in $500 \mathrm{~L} \cdot \mathrm{ha}^{-1}$ of water. The first fungicide treatments were applied when plants were $20-30 \mathrm{~cm}$ high and 1 to 2 days prior to inoculation, to test the protectant effects of the fungicides. This is consistent with provincial recommendations to start spray programs when plants are one-third grown (OMAFRA 2006). Treatment applications began with either Bravo or Pristine.

\section{Inoculation}

Trials were inoculated when plants were $20-30 \mathrm{~cm}$ high using diseased foliage from celery plants with sporulating lesions of S. apiicola on 28 July 2005 (Trial 1), 11 August 2005 (Trial 2), and 3 August 2006 (Trial 3). Inoculum was prepared from diseased tissue by chopping fresh foliage into $1-3 \mathrm{~cm}^{3}$ pieces, mixing with water, and soaking for $2 \mathrm{~h}$ to release conidia (one part foliage to three parts water). The tissue-water suspension was then poured as evenly as possible over plants in the middle two rows of each main plot, such that one row of each subplot was inoculated, and the inoculated rows were adjacent to the row that was subsequently assessed for disease in each subplot.

Plots were irrigated using solid-set overhead sprinklers for $1 \mathrm{~h}$ prior to inoculation in Trials 1 and 2 . Trial 3 was not irrigated because it rained before and after inoculation. All of the trials were irrigated with approximately $3 \mathrm{~cm}$ of water every 1 to 2 weeks to encourage the onset of disease. No disease symptoms were observed prior to inoculation in Trials 1 and 2. Septoria late blight symptoms (1\%-2\% foliar area affected) were observed in some treatments prior to inoculation in Trial 3.

\section{Leaf wetness and temperature}

Hourly temperature and leaf wetness duration data were collected using a HMP35C temperature and relative humidity probe and six Campbell Scientific Model 237 electrical impedance leaf wetness sensors connected to a Campbell Scientific CR21X data logger (Campbell Scientific Corp., Edmonton, Alta). The leaf wetness sensors were placed within the crop canopy $30 \mathrm{~cm}$ above the soil surface at a $45^{\circ}$ angle facing north. The sensors were painted with two coats of off-white exterior acrylic latex paint prior to placement. Hygroscopic properties of the paint were eliminated by heating the sensors at $100{ }^{\circ} \mathrm{C}$ overnight and soaking in distilled water for $4-5 \mathrm{~h}$ after each coat of paint was applied 
(Gillespie and Duan 1987; Sentelhas et al. 2004). Rainfall was recorded using a tipping bucket rain gauge connected to a Campbell Scientific CR21X data logger. The amount of water applied through overhead sprinkler irrigation was recorded with a manual rain gauge within $20 \mathrm{~m}$ of the plot. Growing degree-days (GDD) were calculated as follows (OMAFRA 2006):

$$
\begin{aligned}
\mathrm{GDD}= & {[(\text { daily maximum temperature }} \\
& \quad+\text { daily minimum temperature }) / 2]-5
\end{aligned}
$$

and summed over the days the plants were in the field.

\section{Disease assessment and yield}

Septoria late blight severity was assessed as the percent of visible lesions on foliage in the centre $3 \mathrm{~m}$ of the middle row of each subplot, 1-2 times per week from inoculation until harvest. Severity was assessed using a scale from 0 to 5, where: $0=0 \% ; 1<2 \% ; 2=2 \%-4 \% ; 3=5 \%-9 \% ; 4=$ $10 \%-24 \%$; and $5>25 \%$ foliar area with lesions. These scale values were used to calculate the area under the disease progress curve (AUDPC) using the following equation:

$$
\mathrm{AUDPC}=\sum\left[\left(X_{i+1}+X_{i}\right) / 2 \times\left(t_{i+1}-t_{i}\right)\right]
$$

where $X_{i+1}$ is disease severity rating at day $t_{i+1}$ and $X_{i}$ is disease severity rating at day $t_{i}$ (Shanner and Finney 1977).

Harvest and assessment was conducted over 2 days, with two replications on each day, because of the time required for the assessments. A sample of 12 plants was harvested from each subplot at 51 and 54 days after first application (DAFA) in Trial 1 (16 and 19 September 2005), at 54 and 56 DAFA in Trial 2 (3 and 5 October 2005), and at 48 and 50 DAFA in Trial 3 (18 and 20 September 2006). The weight of each plant was recorded. Then 'Sabroso' plants were trimmed to a $55 \mathrm{~cm}$ length, the standard length for processing celery, and 'Florida 683' plants were trimmed to $40 \mathrm{~cm}$, the standard length for fresh-market celery, and the weight of the trimmed plants was recorded. After trimming, leaves on the trimmed plants were assessed for septoria late blight and rated on a $0-3$ scale, where $0=$ no lesions on leaves, $1<10 \%$ of leaves with lesions, $2=10 \%-49 \%$, and 3 $>50 \%$ with lesions, to calculate a leaf blight index (LBI) (Trueman et al. 2005). Ten outer stalks were removed from each plant, and these 120 petioles per subplot were rated for septoria late blight using a $0-5$ scale, where $0=0 \%, 1<10 \%$, $2=10 \%-24 \%, 3=25 \%-49 \%, 4=50 \%-74 \%$, and $5 \geq 75 \%$ petiole area diseased to calculate the petiole disease severity index (DSI), based on the method of Kobriger and Hagedorn (1983) originally developed for root rot severity:

DSI or LBI $=\frac{\sum[(\text { class No. })(\text { no. of petioles in each class })]}{\text { (total no. petioles per sample })(\text { no. classes }-1)} \times 100$

The fungicide cost for each treatment was calculated by multiplying the number of sprays by the application rate and estimated product cost. In 2006, marketable weight was determined after petiole disease assessment by stripping plants of any diseased petioles and weighing the remaining plant plus any ' 0 ' rated petioles. The percent reduction in marketable yield was determined by dividing weight loss (the difference between marketable weight and trimmed weight) by trimmed weight and multiplying by 100 .
Marketable weight was not assessed in 2005 , so yield reduction was calculated only for the trial in 2006.

\section{Statistical analysis}

Each trial was organized in a factorial design with forecasting system and fungicide regime as the main factors and cultivar as a split block factor. However, for analysis, each combination of fungicide timing program and fungicide regime was considered a separate treatment, to allow comparisons among each combination. Differences between the two fungicide regimes were investigated through singledegree-of-freedom contrasts. Statistical analyses were performed using Proc Univariate and Proc Mixed in SAS v. 8.02 (SAS Institute Inc., Cary, N.C.). Data were tested for normality using the Shapiro-Wilk test and outliers were identified using Lund's test of standardized residuals (Lund 1975). Data were removed for those plots in Trial 3 where infection occurred prior to inoculation and initiation of fungicide treatments. Values for AUDPC and LBI were normalized using a square root transformation prior to analysis.

Data for all three trials were analyzed together. Analysis of variance of the combined data was conducted using Proc Mixed; timing treatments, fungicide regime, and cultivar were treated as fixed factors, and trial was treated as a random factor. Least-square means were separated using Tukey's test. Single-degree-of-freedom contrasts were used to assess differences between Bravo and Pristine treatments for each response variable.

A simple cost analysis was calculated for each treatment to compare the direct cost of the fungicide applied for that treatment based on product prices in 2006. A comprehensive analysis would include expenses associated with fungicide application, crop scouting, assessment of weather parameters, and costs associated with marketing, such as labour costs for stripping off infected petioles. A comprehensive analysis was beyond the scope of the current study, therefore only the direct costs of fungicide were assessed.

\section{Results}

\section{Weather conditions}

Total growing degree-days were 1891, 1674, and 1706 for Trials 1,2, and 3, respectively. Total rainfall plus estimated irrigation for each trial was $152+40,142+40$, and $348+60 \mathrm{~mm}$, for Trials 1,2 , and 3 , respectively.

\section{Fungicides and timing}

The number of fungicide applications varied with year, but was lower for all forecasting treatments than for the calendar spray program in all three trials (Table 2). The Septoria Predictor reduced the number of spray applications by 1 relative to the calendar spray program in each trial. Use of the Tomcast program resulted in a reduction of 1 to 3 sprays at a DSV threshold of 10 and 2 to 4 sprays at a DSV threshold of 15 . Tomcast at a DSV threshold of 20 provided the greatest spray reduction in all three trials; the number of applications was reduced by 3 in Trial 1, 5 in Trial 2, and 4 in Trial 3. 
Table 2. Number of spray applications and application dates (based on days after first application (DAFA)) for disease forecasting programs tested for management of septoria late blight of celery at the Holland-Bradford Marsh, Ontario, in 2005 (Trials 1 and 2) and 2006 (Trial 3).

\begin{tabular}{|c|c|c|c|c|c|c|}
\hline \multirow[b]{2}{*}{ Treatment* } & \multicolumn{2}{|l|}{ Trial 1} & \multicolumn{2}{|l|}{ Trial 2} & \multicolumn{2}{|l|}{ Trial 3} \\
\hline & DAFA $^{\dagger}$ & No. sprays & $\mathrm{DAFA}^{\dagger}$ & No. sprays & DAFA $^{\dagger}$ & No. sprays \\
\hline Nonsprayed control & - & 0 & - & 0 & - & 0 \\
\hline $\begin{array}{l}\text { Calendar } \\
\text { Pristine/Champ } \\
\text { Bravo/Champ }\end{array}$ & $\begin{array}{l}0,6,13,20 \\
27,33,41\end{array}$ & 7 & $\begin{array}{l}0,7,14,20 \\
28,35,42,47\end{array}$ & 8 & $\begin{array}{l}0,8,15, \\
22,29,36^{\ddagger}\end{array}$ & 6 \\
\hline $\begin{array}{l}\text { Tomcast DSV } 10 \\
\text { Pristine/Champ } \\
\text { Bravo/Champ }\end{array}$ & $\begin{array}{l}0,6,13,20 \\
27,37\end{array}$ & 6 & $\begin{array}{l}0,7,14,24 \\
40\end{array}$ & 5 & $\begin{array}{l}0,8,21, \\
28^{\ddagger}\end{array}$ & 4 \\
\hline $\begin{array}{l}\text { Tomcast DSV } 15 \\
\text { Pristine/Champ } \\
\text { Bravo/Champ }\end{array}$ & $\begin{array}{l}0,8,18,33, \\
37\end{array}$ & 5 & $0,7,20,40$ & 4 & $0,17,28$ & 3 \\
\hline $\begin{array}{l}\text { Tomcast DSV } 20 \\
\text { Pristine/Champ } \\
\text { Bravo/Champ }\end{array}$ & $0,8,20,40$ & 4 & $0,10,27$ & 3 & $0,21^{\stackrel{+}{*}}$ & 2 \\
\hline $\begin{array}{l}\text { Septoria Predictor } \\
\text { Pristine/Champ } \\
\text { Bravo/Champ }\end{array}$ & $\begin{array}{l}0,8,18,{ }^{\S} \\
27,33,41\end{array}$ & 6 & $\begin{array}{l}0,10,16{ }^{\S} 27, \\
35,42,47\end{array}$ & 7 & $\begin{array}{l}0,15,^{\S} 22, \\
29,36^{\ddagger}\end{array}$ & 5 \\
\hline
\end{tabular}

\section{Disease severity}

Disease severity (assessed as DSI, LBI, and AUDPC) was the highest in Trial 2 (Table 3). Fungicide application reduced petiole DSI and LBI in all trials compared with the nonsprayed control, with the exception of LBI for the Tomcast program using a DSV threshold of 10 with Bravo/Champ in Trial 2 (Table 3). All of the fungicide treatments had lower AUDPC compared with the nonsprayed control in Trials 1 and 2, and all treatments sprayed with Pristine had lower AUDPC relative to the nonsprayed control in Trial 3. AUDPC values were six times higher in the nonsprayed control than the least effective fungicide treatments in Trial 1, two times higher in Trial 2, and three times higher in Trial 3. Contrasts showed that the AUDPC and LBI were lower in treatments with Pristine than with Bravo (Table 3). There was no difference in petiole DSI between Pristine and Bravo in Trials 1 or 3 , but DSI was lower for treatments with Pristine than with Bravo in Trial 2.

The Septoria Predictor was as effective as the calendar spray program for all measurements of disease severity except AUDPC in Trial 2, where calendar sprays of Pristine/Champ provided more effective disease reduction than treatments applied as indicated by the Septoria Predictor. The Tomcast program was as effective as the calendar sprays in maintaining low petiole DSI. The only exceptions were for Bravo/Champ applied based on Tomcast at DSV 10 or 20 in Trial 2. Sprays applied according to Tomcast DSV 10 or 15 were as effective as the calendar program at reducing LBI and more effective than the Tomcast DSV 20 program in Trials 1 and 3 (Table 3). Under high disease pressure in Trial 2, none of the Tomcast thresholds with Pristine were as effective as Pristine applied on a calendar basis. Tomcast DSV 15 with Bravo/Champ was as effective as the calendar program with Bravo/Champ, but not as effective as calendar sprays of Pristine/Champ.

The effect of spray program on AUDPC varied, but the calendar spray program provided the most effective disease reduction across the trials. In Trial 3 (lowest AUDPC in the nonsprayed control), all programs were as effective as the calendar program. In Trial 2 (highest AUDPC in the control), the forecasting programs were generally less effective than the calendar spray. In Trial 1, all of the treatments with Bravo/Champ were as effective as Bravo/Champ applied on a calendar basis. However, the lowest AUDPC was achieved with Pristine applied as indicated by each program except Tomcast at DSV 20.

In all three trials, both cultivars ('Sabroso' and 'Florida 683') were highly susceptible to Septoria late blight. Cultivars had no consistent effect on disease severity in any trial (data not shown).

\section{Yield}

All fungicide applications increased trimmed weight compared with the nonsprayed control, as determined by single-degree-of-freedom contrasts (Table 4). When treatments were compared individually with the nonsprayed 
Table 3. Petiole disease severity index (DSI), leaf blight index (LBI), and area under the disease progress curve (AUDPC) in celery produced using five fungicide spray programs for management of septoria late blight at the Holland-Bradford Marsh, Ontario, in 2005 (Trials 1 and 2) and 2006 (Trial 3).

\begin{tabular}{|c|c|c|c|c|c|c|c|}
\hline \multirow[b]{2}{*}{ Treatment* } & \multicolumn{2}{|l|}{$\mathrm{DSI}^{\dagger}$} & \multicolumn{2}{|l|}{$\mathrm{LBI}^{\dagger, \dagger}$} & \multicolumn{3}{|c|}{ AUDPC $^{\dagger, \ddagger}$} \\
\hline & $\begin{array}{l}\text { Trial } \\
1 \text { and } 3\end{array}$ & Trial 2 & $\begin{array}{l}\text { Trial } \\
1 \text { and } 3\end{array}$ & Trial 2 & Trial 1 & Trial 2 & Trial 3 \\
\hline Nonsprayed control & $34.3 \mathrm{~b}$ & $60.4 \mathrm{c}$ & $87.2 \mathrm{f}$ & $100.0 \mathrm{~d}$ & $62.1 \mathrm{~d}$ & $94.5 \mathrm{~h}$ & $48.8 \mathrm{~b}$ \\
\hline \multicolumn{8}{|l|}{ Calendar } \\
\hline Pristine/Champ & $0.0 \mathrm{a}$ & $0.3 \mathrm{a}$ & $0.5 \mathrm{a}$ & $12.4 \mathrm{a}$ & $0.0 \mathrm{a}$ & $3.5 \mathrm{a}$ & $2.3 \mathrm{a}$ \\
\hline Bravo/Champ & $0.0 \mathrm{a}$ & $1.7 \mathrm{a}$ & $9.0 \mathrm{bcd}$ & $30.6 \mathrm{ab}$ & $3.5 \mathrm{bc}$ & $24.2 \mathrm{def}$ & $9.2 \mathrm{a}$ \\
\hline \multicolumn{8}{|l|}{ Tomcast DSV 10} \\
\hline Pristine/Champ & $0.0 \mathrm{a}$ & $1.5 \mathrm{a}$ & $1.7 \mathrm{abc}$ & $45.6 \mathrm{bc}$ & $0.1 \mathrm{a}$ & $19.1 \mathrm{~cd}$ & $4.9 \mathrm{a}$ \\
\hline Bravo/Champ & $0.1 \mathrm{a}$ & $11.4 \mathrm{~b}$ & $10.3 \mathrm{~cd}$ & $70.7 \mathrm{~cd}$ & $0.6 \mathrm{ab}$ & $35.9 \mathrm{fg}$ & $9.4 \mathrm{ab}$ \\
\hline \multicolumn{8}{|l|}{ Tomcast DSV 15} \\
\hline Pristine/Champ & $0.0 \mathrm{a}$ & $1.4 \mathrm{a}$ & $4.5 \mathrm{abc}$ & $32.3 \mathrm{~b}$ & $0.0 \mathrm{a}$ & $14.1 \mathrm{bc}$ & $4.0 \mathrm{a}$ \\
\hline Bravo/Champ & $0.0 \mathrm{a}$ & $3.6 \mathrm{ab}$ & $20.7 \mathrm{de}$ & $40.7 \mathrm{bc}$ & $7.8 \mathrm{c}$ & $22.2 \mathrm{cde}$ & $12.0 \mathrm{ab}$ \\
\hline \multicolumn{8}{|l|}{ Tomcast DSV 20} \\
\hline Pristine/Champ & $0.5 \mathrm{a}$ & $5.5 \mathrm{ab}$ & $15.1 \mathrm{~d}$ & $61.3 \mathrm{c}$ & $3.7 \mathrm{bc}$ & 29.3 def & $5.8 \mathrm{a}$ \\
\hline Bravo/Champ & $0.4 \mathrm{a}$ & $12.6 \mathrm{~b}$ & $41.6 \mathrm{e}$ & $61.7 \mathrm{c}$ & $10.3 \mathrm{c}$ & $43.9 \mathrm{~g}$ & $16.2 \mathrm{ab}$ \\
\hline \multicolumn{8}{|l|}{ Septoria Predictor } \\
\hline Pristine/Champ & $0.0 \mathrm{a}$ & $0.1 \mathrm{a}$ & $0.8 \mathrm{ab}$ & $12.3 \mathrm{a}$ & $0.9 \mathrm{ab}$ & $9.4 \mathrm{~b}$ & $5.4 \mathrm{a}$ \\
\hline Bravo/Champ & $0.1 \mathrm{a}$ & $5.2 \mathrm{ab}$ & $6.5 \mathrm{abcd}$ & $44.6 \mathrm{bc}$ & $7.3 \mathrm{c}$ & 32.2 efg & $10.8 \mathrm{a}$ \\
\hline \multicolumn{8}{|l|}{ Contrasts } \\
\hline Pristine/Champ & $0.1 \mathrm{~ns}$ & $1.8 \mathrm{a}$ & $4.5 \mathrm{a}$ & $32.8 \mathrm{a}$ & $0.9 \mathrm{a}$ & $15.1 \mathrm{a}$ & $4.5 \mathrm{a}$ \\
\hline Bravo/Champ & 0.1 & $6.9 \mathrm{~b}$ & $17.6 \mathrm{~b}$ & $50.0 \mathrm{~b}$ & $5.8 \mathrm{~b}$ & $31.7 \mathrm{~b}$ & $11.5 \mathrm{~b}$ \\
\hline
\end{tabular}

control, the only treatments that increased trimmed weight on both cultivars were the calendar program with Bravo and the Tomcast program at DSV 10 with Pristine. The yield of 'Florida 683' sprayed with Pristine, following the Septoria Predictor, was also higher than the nonsprayed treatment. All fungicide treatments increased market weight and limited the reduction in marketable yield in 2006. Applications of Pristine increased marketable yield by $10 \%$. The difference between trimmed weight and marketable weight was $6 \%$ less than treatments sprayed with Bravo (Table 4). Processing celery 'Sabroso' was consistently heavier than 'Florida 683' (1.40 kg.plant ${ }^{-1}$ and $1.06 \mathrm{~kg} \cdot \mathrm{plant}^{-1}$, respectively, for celery treated with Pristine/Champ).

\section{Cost analysis}

Fungicide costs, calculated across the three trials and based on 2006 prices, ranged from $\$ 82$ to $\$ 736$ depending on trial, spray program, and fungicide (Table 5). Costs for the calendar application program with Bravo/Champ ranged from $\$ 245$ to $326 \mathrm{ha}^{-1}$, and from $\$ 552$ to $736 \mathrm{ha}^{-1}$ for Pristine/Champ. The lowest cost was incurred with the Tomcast DSV 20 program, at \$82-163 ha-1 for Bravo/Champ and \$184-368 ha ${ }^{-1}$ for Pristine/Champ. This spray program was the least costly because it called for the fewest fungicide applications.

\section{Discussion}

Effective management of septoria late blight is essential for the production of a marketable crop of celery. The disease threshold for celery is effectively zero because plants with noticeable lesions on leaves and petioles are unmarketable, so diseased petioles must be removed by hand. This study demonstrated that application of the fungicides Bravo/Champ or Pristine/Champ, timed as indicated by the Tomcast and Septoria Predictor forecasting programs, provide effective management of septoria late blight with fewer fungicide applications than a calendar spray program. All fungicide programs based on forecasting reduced disease severity relative to the nonsprayed control, but Pristine, which is a reduced-risk fungicide, was consistently more effective than Bravo in reducing leaf blight severity and AUDPC. As expected, both of the cultivars that were assessed were highly susceptible to septoria late blight; there were no consistent differences in levels of disease between cultivars in any of the trials.

Disease management using the Septoria Predictor program was generally as effective as the calendar spray program, but required one less fungicide application. Fungicides applied according to Tomcast with a DSV threshold of 10 or 15 reduced LBI as effectively as the calendar 
Table 4. Trimmed weight, market weight, and percent yield reduction for celery 'Florida 683' and 'Sabroso' grown using five fungicide spray programs for management of septoria late blight at the Holland-Bradford Marsh, Ontario, in two trials in 2005 and one trial in 2006.

\begin{tabular}{|c|c|c|c|c|}
\hline \multirow[b]{2}{*}{ Treatment* } & \multicolumn{2}{|c|}{ Trimmed weight $\left(\mathrm{kg} \cdot \text { plant }^{-1}\right)^{\dagger}$} & \multirow{2}{*}{$\begin{array}{l}\text { Market weight } \\
(2006)\left(\mathrm{kg} \cdot \text { plant }^{-1}\right)\end{array}$} & \multirow{2}{*}{$\begin{array}{l}\text { Yield reduction } \\
2006(\%)\end{array}$} \\
\hline & 'Florida 683' & 'Sabroso' & & \\
\hline Nonsprayed control & $0.79 \mathrm{~b}$ & $1.11 \mathrm{~b}$ & $0.43 \mathrm{c}$ & $63 \mathrm{c}$ \\
\hline \multicolumn{5}{|l|}{ Calendar } \\
\hline Pristine/Champ & $1.05 \mathrm{ab}$ & $1.36 \mathrm{ab}$ & $1.49 \mathrm{a}$ & $1 \mathrm{a}$ \\
\hline Bravo/Champ & $1.06 \mathrm{a}$ & $1.50 \mathrm{a}$ & $1.41 \mathrm{ab}$ & $4 \mathrm{ab}$ \\
\hline \multicolumn{5}{|l|}{ Tomcast DSV 10} \\
\hline Pristine/Champ & $1.10 \mathrm{a}$ & $1.52 \mathrm{a}$ & $1.38 \mathrm{ab}$ & $2 a b$ \\
\hline Bravo/Champ & $1.00 \mathrm{ab}$ & $1.31 \mathrm{ab}$ & $1.29 \mathrm{ab}$ & $3 a b$ \\
\hline \multicolumn{5}{|l|}{ Tomcast DSV 15} \\
\hline Pristine/Champ & $1.02 \mathrm{ab}$ & $1.32 \mathrm{ab}$ & $1.43 \mathrm{ab}$ & $1 \mathrm{a}$ \\
\hline Bravo/Champ & $0.98 \mathrm{ab}$ & $1.28 \mathrm{ab}$ & $1.10 \mathrm{~b}$ & $15 \mathrm{~b}$ \\
\hline \multicolumn{5}{|l|}{ Tomcast DSV 20} \\
\hline Pristine/Champ & $1.04 \mathrm{ab}$ & $1.39 \mathrm{ab}$ & $1.43 \mathrm{ab}$ & $1 \mathrm{a}$ \\
\hline Bravo/Champ & $1.02 \mathrm{ab}$ & $1.31 \mathrm{ab}$ & $1.28 \mathrm{ab}$ & $10 \mathrm{ab}$ \\
\hline \multicolumn{5}{|l|}{ Septoria Predictor } \\
\hline Pristine/Champ & $1.09 \mathrm{a}$ & $1.40 \mathrm{ab}$ & $1.38 \mathrm{ab}$ & $0 \mathrm{a}$ \\
\hline Bravo/Champ & $1.01 \mathrm{ab}$ & $1.39 \mathrm{ab}$ & $1.39 \mathrm{ab}$ & $1 \mathrm{a}$ \\
\hline \multicolumn{5}{|l|}{ Contrasts } \\
\hline Pristine/Champ & $1.06 \mathrm{~ns}$ & $1.40 \mathrm{~ns}$ & $1.42 \mathrm{a}$ & $1 \mathrm{a}$ \\
\hline Bravo/Champ & 1.01 & 1.36 & $1.29 \mathrm{~b}$ & $7 \mathrm{~b}$ \\
\hline Nonsprayed control & $0.79 \mathrm{~b}$ & $1.11 \mathrm{~b}$ & $0.43 \mathrm{~b}$ & $63 \mathrm{~b}$ \\
\hline Any fungicide & $1.04 \mathrm{a}$ & $1.38 \mathrm{a}$ & $1.36 \mathrm{a}$ & $4 \mathrm{a}$ \\
\hline
\end{tabular}

Note: Numbers in a column followed by the same letter are not significantly different at $P=0.05$ using ANOVA, Tukey's adjustment; and ns, not significant.

*Pristine WG at $1.0 \mathrm{~kg} \cdot \mathrm{ha}^{-1}$, Champ 2FL at $4.0 \mathrm{~kg} \cdot \mathrm{ha}^{-1}$, Bravo 500 at $3.0 \mathrm{~L} \cdot \mathrm{ha}^{-1}$.

${ }^{\dagger}$ Data from each cultivar was separated because of a significant cultivar $\times$ treatment interaction at $P=0.05$ in ANOVA.

program in two of the three trials, and the Tomcast DSV 15 program with Pristine was also effective in the third trial.

Yield loss (\% reduction in marketable yield) was numerically highest in Trial 3 for Tomcast at DSV 15 with Bravo, relative to the other fungicide treatments. Although this difference was not statistically significant, it indicates that the DSV 15 threshold with Bravo/Champ fungicides may not consistently provide an acceptable level of disease control.

The Tomcast program at DSV 20 resulted in the greatest reduction in the number of fungicide applications, but did not provide acceptable disease control. Disease severity (DSI and LBI) for Trial 2 was higher for Tomcast DSV 20 with Bravo than for the calendar program with Bravo. Spray intervals for Tomcast DSV 20 treatments ranged from 8 to 21 days across the three trials, therefore, leaf wetness events likely occurred when the previous application of protectant fungicide (Bravo or Champ) was no longer effective. As a result, disease control for the Tomcast DSV 20 Bravo/Champ treatment was compromised. Although differences between the Tomcast DSV 20 treatment and the other treatments were not always significant, we conclude that this long interval between fungicide applications substantially increased the risk of crop loss due to septoria late blight. This risk would increase even more if weather factors (e.g., rain, high winds) delayed fungicide application when the threshold was reached.

Similarly, LBI was higher for the Tomcast DSV 20 treatment with Pristine compared with DSV 10 and 15 in the first two trials, and with DSV 15 in the third trial. Boscalid and pyraclostrobin possess both curative and protectant activity, thus, the application of these products post-infection likely provided some disease reduction (Bartlett et al. 2002). However, post-infection application of these materials is not recommended because it increases the risk of fungicide resistance.

For all the treatments with Pristine, marketable weight per plant was $0.13 \mathrm{~kg}$ higher and yield reduction was $6 \%$ less than with Bravo in 2006. The application of strobilurin fungicides has been associated with a "greening effect" independent of disease control in wheat (Bartlett et al. 2002; Gerhard et al. 1999). However, there were no differences between Pristine and Bravo treatments for height (data not shown), harvest weight, or trimmed weight, indicating that higher yield was likely the result of improved disease management. Marketable yield was not measured in Trials 1 and 2, but yield losses and labour costs in these trials would also have been higher for treatments with Bravo than with Pristine based on levels of DSI. For example, DSI in Trial 2 
Table 5. Estimated costs of fungicide for management of septoria late blight of celery produced under five fungicide timing regimes at the Holland-Bradford Marsh, Ontario, in 2005 (Trials 1 and 2) and 2006 (Trial 3).

\begin{tabular}{lcccc}
\hline & \multicolumn{4}{l}{ Cost $\left(\$ \mathrm{ha}^{-1}\right)$} \\
\cline { 2 - 5 } Treatment & Trial 1 & Trial 2 & Trial 3 & Mean \\
\hline Nonsprayed control & 0 & 0 & 0 & 0 \\
Calendar program & & & & \\
Pristine/Champ & 692 & 736 & 552 & 660 \\
Bravo/Champ & 282 & 326 & 245 & 284 \\
Tomcast DSV 10 & & & & \\
Pristine/Champ & 552 & 552 & 368 & 491 \\
Bravo/Champ & 245 & 201 & 163 & 203 \\
Tomcast DSV 15 & & & & \\
Pristine/Champ & 508 & 368 & 324 & 400 \\
Bravo/Champ & 201 & 163 & 119 & 161 \\
Tomcast DSV 20 & & & & \\
Pristine/Champ & 368 & 324 & 184 & 292 \\
Bravo/Champ & 163 & 119 & 82 & 121 \\
Septoria Predictor & & & & \\
Pristine/Champ & 552 & 692 & 508 & 584 \\
Bravo/Champ & 245 & 282 & 201 & 243 \\
\hline
\end{tabular}

Note: Costs are estimates based on 2006 prices from BASF Corp., application rate, and number of applications as follows: Pristine $\mathrm{WG}=$ $\left(1.0 \mathrm{~kg} \cdot \mathrm{ha}^{-1}\right)\left(\$ 140 \mathrm{~kg}^{-1}\right)($ no. applications $) ;$ Champ $2 \mathrm{FL}=\left(4.0 \mathrm{~L} \cdot \mathrm{ha}^{-1}\right)$ $\left(\$ 11.00 \mathrm{~L}^{-1}\right)$ (no. applications); and Bravo $500=\left(3.0 \mathrm{~L}^{-\mathrm{ha}^{-1}}\right)\left(\$ 12.50 \mathrm{~L}^{-1}\right)$ (no. applications).

for Bravo treatments was 6.9 compared with 1.8 for Pristine, which represents 42 petioles with disease (78 diseasefree petioles) for treatments with Bravo versus 11 diseased petioles (109 disease-free petioles) with Pristine. Lesions in treatments with Pristine/Champ were visually smaller than with Bravo/Champ, but lesion size was not measured.

Celery treated with fungicide consistently had higher yields than the nonsprayed control. Yield losses of $63 \%$ in the nonsprayed control in Trial 3 are consistent with a report of losses up to $70 \%$ in Michigan (Lacy et al. 1996). In the control treatment, only the inner portion of the celery heart was marketable. Also, even the calendar program did not provide acceptable disease control under the high disease pressure that occurred in Trial 2, especially as assessed by the presence of lesions on leaves after trimming (LBI).

One treatment in Trial 2 differed from its equivalent in Trials 1 and 3, in that disease severity (DSI, LBI, and AUDPC) was higher for Tomcast DSV 10 with Bravo than for the calendar spray program. In Trial 2, fungicide application was delayed because of rain and wind on one occasion during the study period, so the treatment was four DSV units over threshold when the fungicide was applied. As a result, disease was more severe for Tomcast DSV 10 compared with DSV 15. Also, AUDPC values for both fungicide rotations at DSV 10 were similar to the equivalent fungicide rotation at DSV 20. These results indicate that spraying prior to rain events when approaching the DSV threshold is necessary for optimal management of septoria late blight.
The results of this study are similar to recent findings in Michigan by Bounds and Hausbeck (2007). They concluded that Tomcast DSV 10 resulted in the greatest reduction in the number of sprays while maintaining an acceptable level of disease control. They observed larger differences in disease severity among Tomcast DSV 10, 15, and 20 treatments than were found in the current study. While this may be a result of differences in inoculation, assessment methods, or environmental conditions, it probably reflects the differences in the fungicides tested. Our results indicate that Tomcast at a DSV threshold of 15 provides an adequate spray interval when Pristine is used in rotation with Champ.

The cost of treatments differed with the number of applications and the cost of the products themselves. Tomcast at DSV 10 reduced the number of sprays per season by 1 to 3 relative to a calendar spray program; product costs were $\$ 169 \mathrm{ha}^{-1}$ lower for the rotation with Pristine and \$81 ha $\mathrm{h}^{-1}$ lower for Bravo. For Tomcast at DSV 15, the number of sprays was reduced by 2 to 4 , and costs were $\$ 260$ lower for Pristine and \$123 lower for Bravo. The Septoria Predictor provided the smallest cost savings; following canopy closure, a regular calendar spray program was implemented and the number of fungicide applications per trial was only reduced by one. The cost of Pristine/Champ in a calendar spray program was approximately 2.4 times higher than Bravo/Champ, based on prices in 2006.

This simple cost analysis only compares fungicide costs. A more comprehensive analysis would include application costs and the costs of crop scouting. This can be difficult to determine since scouting programs involve more than a single disease, and fungicide applications may be tank mixed with insecticides or foliar fertilizers. Costs will vary by location, service provider, and volume. The cost of scouting with the University of Guelph pest management program on the Holland-Bradford Marsh begins at \$50 per acre, with the cost decreasing with increasing area scouted. Additionally, adoption of disease forecasting programs also depends on the production practices of individual growers, including labour costs, harvest and grading methods, production of processing or fresh market celery, and risk tolerance.

Implementation of the Septoria Predictor or Tomcast programs requires a recommendation for initiating fungicide application. There was no difference in levels of septoria late blight in Michigan when fungicide applications were initiated 2 or 5 weeks after transplanting (Bounds and Hausbeck 2006). The recommendation for Ontario is that fungicide applications for septoria late blight begin onethird of the way through the growing season or as soon as symptoms are seen in the field (OMAFRA 2006). In the current study, inoculation and monitoring of leaf wetness and temperature began 7 to 10 weeks after transplanting, so a DSV threshold was not used to time the first application. Until further testing is conducted, timing of the first fungicide application in accordance with current Ontario recommendations appears to be a good option. The first spray may need to be applied earlier if the field is close to infected fields, has a history of the disease, if conditions are highly conducive for disease (e.g., long dew periods in late summer), or if the canopy closes more quickly than usual. These recommendations are based on knowledge that during rain events spores may travel to adjacent fields located 
downwind and that infected plant residue can survive 9 to 18 months (Maude and Shuring 1970; Sutton and Waterston 1966) and canopy closure results in longer periods of leaf wetness, which are favourable for the development of septoria late blight (Lacy 1994).

If growers are to adopt the Septoria Predictor or Tomcast forecasting programs, they need to have access to reliable temperature and leaf wetness information. The timing of fungicide application in this study was based on mean readings from six sensors within the crop canopy. As demonstrated in Trial 2 with Tomcast DSV 10, a delay of even a few days can result in reduced disease control. Use of sensors linked to a datalogger requires extensive investment in equipment and training, and leaf wetness can vary considerably within small geographic regions (Sutton et al. 1984). Also, the timing of celery plantings is staggered from May to July to meet market demand. Leaf wetness duration is affected by canopy size, thus, it is not possible to extrapolate leaf wetness information to fields at different stages of development. Therefore, availability of weather data may be the most important constraint on the adoption of these forecasting systems in commercial production systems.

This study is the first validation of disease forecasting systems for control of septoria late blight of celery under Ontario conditions. The use of disease forecasting systems to indicate when to apply fungicide resulted in effective management of septoria late blight by reducing the number fungicide applications by 1 to 4 sprays, even under conditions of high disease pressure. Methods to time the first fungicide application are required to further improve disease management. Cultivars, sprayer type, and production methods were similar to those used by commercial growers, and results were consistent over the three trials. Our results support the recommendation that fungicide applications based on spray timings for Tomcast with a DSV threshold of 10 and the Septoria Predictor replace a regular 7-day calendar spray program. Use of the Tomcast program with a DSV threshold of 15 could further reduce the number of sprays required for disease management if Pristine is used. Pristine is not yet registered for use on celery in Canada and costs 2.4 times more than Bravo. However, Pristine is more effective at managing septoria late blight, and its use, when registered, would reduce time and labour requirements for removal of diseased plant material.

\section{Acknowledgements}

Special thanks for assistance from Kevin Vander Kooi, Marilyn Hovius, and Sean Westerveld. This research was supported by the Natural Sciences and Engineering Research Council, the Bradford \& District Co-op, the New Directions Program Ontario Ministry of Agriculture Food and Rural Affairs, the Ontario Ministry of Agriculture Food and Rural Affairs - University of Guelph Plant Program, and the Agricultural Adaptation Council with the support of the Fresh Vegetable Growers of Ontario.

\section{References}

Bartlett, D.W., Clough, J.M., Godwin, J.R., Hall, A.A., Hamer, M., and Parr-Dobrzanski, B. 2002. The strobilurin fungicides. Pest Manag. Sci. 58: 649-662.

Bolkan, H.A., and Reinert, W.R. 1994. Developing and implementing IPM strategies to assist farmers: an industry approach. Plant Dis. 78: 545-550.

Bounds, R.S., and Hausbeck, M.K. 2007. Comparing disease predictors and fungicide programs for late blight management in celery. Plant Dis. 91: 532-537.

Bounds, R.S., and Hausbeck, M.K. 2006. Evaluation of spray initiation timings for managing late blight of celery, 2004 [online]. Fungicide and Nematicide Tests. 61: V124. Available from http://www.plantmanagementnetwork.org/pub/trial/fntests/vol61/ [accessed February 2007].

Cerkauskus, R.F. 1994. Septoria blight (late blight). In Disease and pests of vegetable crops in Canada: an illustrated compendium. Edited by J. Howard, A. Garland, and W.L. Seaman. Canadian Phytopathological Society and Entomological Society of Canada. Ottawa, Ont. pp. 86-87.

FRAC. 2005. Pathogen risk list [online]. Fungicide Resistance Action Committee. Available from http://www.frac.info/frac/ index.htm [updated December 2005; accessed March 2006].

Gerhard, M., Habermeyer, J., and Zinkernagel, V. 1999. The impact of strobilurins on plant vitality on winter wheat under field conditions. In Modern fungicides and antifungal compounds II. Edited by H. Lyr, P.E. Russell, H.-W. Dehne, and H.D. Sisler. Intercept Limited. Andover, UK. pp. 197-208.

Gillespie, T.J., and Duan, R.-X. 1987. A comparison of cylindrical and flat plate sensors for surface wetness duration. Agric. For. Meteorol. 40: 61-70.

Kobriger, D.M., and Hagedorn, D.J. 1983. Determination of bean root rot potential in vegetable production fields of Wisconsin's Central Sands. Plant Dis. 67: 177-178.

Lacy, M.L. 1994. Influence of wetness periods on infection of celery by Septoria apiicola and use in timing sprays for control. Plant Dis. 78: 975-979.

Lacy, M.L., Berger, R.D., Gilbertson, R.L., and Little, E.L. 1996. Current challenges in controlling diseases of celery. Plant Dis. 80: 1084-1091.

Lund, R.E. 1975. Tables for an approximate test for outliers in linear models. Technometrics, 17: 473-476.

Madden, L., Pennypacker, S.P., and MacNab, A.A. 1978. FAST, a forecast system for Alternaria solani on tomato. Phytopathology, 68: 967-1812.

Mathieu, D., and Kushalappa, A.C. 1993. Effects of temperature and leaf wetness duration on the infection of celery by Septoria apiicola. Phytopathology, 83: 1036-1040.

Maude, R.B. 1970. The control of Septoria on seed. Ann. Appl. Biol. 65: 249-254.

Maude, R.B., and Shuring, C.G. 1970. The persistence of Septoria apiicola on diseased celery debris in soil. Plant Pathol. 19: 177-179.

Mudita, I.W., and Kushalappa, A.C. 1993. Ineffectiveness of the first fungicide application at different initial disease incidence levels to manage septoria blight in celery. Plant Dis. 77: 1081-1084.

OMAFRA. 2006. Celery. In Vegetable production recommendations 2006-2007. Ontario Ministry of Agriculture, Food and Rural Affairs Publication 363. Queen's Printer for Ontario, Toronto, Ont. pp. 89-94. 
Phillips, P.A. 1999. Monitoring disease model microclimates: a perspective on leaf wetness instrumentation pitfalls. UC Plant Prot. Quart. 9: 7-10.

Poysa, V., Brammall, R.A., and Pitblado, R.E. 1993. Effects of foliar fungicide sprays on disease and yield of processing tomatoes in Ontario. Can. J. Plant Sci. 73: 1209-1215.

Sentelhas, P.C., Monteiro, J.E.B.A., and Gillespie, T.J. 2004. Electronic leaf wetness duration sensor: why it should be painted. Int. J. Biometeorol. 48: 202-205.

Shanner, G., and Finney, R.E. 1977. The effect of nitrogen fertilization on the expression of slow-mildewing resistance in Knox wheat. Phytopathology, 67: 1050-1056.
Sutton, B.C., and Waterston, J.M. 1966. Septoria apiicola. CMI descriptions of pathogenic fungi and bacteria, No. 88. The Eastern Press Ltd., London, UK.

Sutton, J.C., Gillespie, T.J., and Hildebrand, P.D. 1984. Monitoring weather factors. Plant Dis. 68: 78-84.

Trueman, C.L., McDonald, M.R., Vander Kooi, K., and McKeown, A. 2005. Evaluation of new chemistry fungicides for the control of Septoria late blight on celery, 2004. Pest Management Research Report, 43: 222-225. Available from http://www.cps-scp.ca/PMRR/common/pmrr_2004.pdf [accessed November 2006]. 